\section{FLOW ENGINEERING}

\section{Theory of Groundwater Flow}

By A. Verruijt. (Macmillan Civil Engineering Hydraulics Series.) Pp. $x+190$. (Macmillan: London, May 1970.) $60 s$.

Thrs book provides a basic introduction to the mathe. matical description and solution of groundwater problems of the type encountered in civil engineering practice. Following a brief résumé of basic soil and water properties in chapter one, two short chapters are devoted to the introduction of Darey's law and Laplace's equation. Elementary problems in confined and semi-confined aquifers, and in unconfined aquifers are then treated in chapters four and five respectively. Chapter six discusses the method of images, followed by an account of potential and stream functions. Functions of a complex variable are introduced in chapter seven, and complex variable techniques, including the hodograph method, are treated in the following chapter. Approximate methods, including the sketching of flow nets and relaxation techniques, are covered in chapter nine, and chapter ten discusses the finite element method. Conducting paper and viscous flow analogues are described briefly in the final chapter, and there is a short appendix on Bessel functions.

The author's presentation is both clear and logical. A number of worked numerical examples are included, and in most chapters some useful comments are provided on the cited references. Metric units are used throughout.

The balance of the book reflects the author's declared enthusiasm for complex variable techniques, with chapters seven and eight comprising almost one-third the length of the text. Chapter ten tends to assume a greater amount of mathematical expertise on the part of the reader than the rest of the book. With these minor reservations, the book should prove particularly useful to postgraduate students in both engineering hydrology and water resources engineering. Civil engineering undergraduates should find all but the more theoretically complicated chapters a useful source of reference. The wide circulation which this book deserves would be greatly enhanced if the publishers could be persuaded to make available a student paperback edition.

M. J. HALI

\section{WHAT'S IT ALL ABOUT, ALFIE?}

\section{Human Engineering}

By Lord Robens. Pp. 186. (Cape: London, July 1970.) $38 s$.

LORD ROBENS is the head of the organization with the largest payroll in Europe and an industry which, since the mid-fifties, has experienced a dramatic improvement in its strike record while at the same time being a chief victim of the technological revolution. The National Coal Board has closed about 500 pits, directly affecting nearly 200,000 miners; it has staggeringly increased productivity and it has made far reaching changes in working methods. That all this was achieved can be no accident, so when it comes to industrial relations, Lord Robens should know what he is talking about. And, indeed, the book is full of the sound commonsense one would expect from a man who was a northern trades union official in the thirties and forties, and his arguments are put forward with the confidence and conviction of a man who has climbed up through the Labour movement into the Attlee government and cabinet to chairman of the National Coal Board. He was a key member of the Royal Commission on Trade Unions and Employers Associations, and is now a director of the Bank of England.

The theme of Lord Robens's book is simple enough: it is that "people count". He believes it "natural and inevitable that each generation will expect and demand a better life than the last. What constitutes a better life lies in the heart and being of the individual, but for the mass, it is represented in growing affluence and a higher standard of living". He goes on to explain that the objective can only be achieved by economic growth and such growth, for a country such as the United Kingdom, is dictated by the growth of world trade and the share of world trade it can capture by trading competitively. But the British, as he points out, are losing their share of world trade because they are not competitive enough: "What, Britain. needs today above all else is industrial efficiency-We cannot survive with an economy running at half capacity".

So how do we become "competitivo and efficient" ? We have, according to Lord Robens, to learn the lessons of the past. "Britain was an industrial pioneer only through the skill and perseverance of her manpower, the inventiveness and genius of her engineers, and the zest and commonsonse of her management. It was the quality of our people alone which interrupted the even procession of history and broke through to fashion an entirely new form of society". Lord Robens argues that Britain's finest asset is her people and she will become great again by the effort of her people. But more than this, "human engineering" is the concept he uses for a programme which enables workers to be fulfilled by their job-and, at the same time, to make the maximum contribution to their work. He says, "every policy and every project should be a permanent quest to reclaim the sunken areas of man's potential and exploit the capacity to take advantage to the full life and its possibilities."

The most important chapter is perhaps the one on "Consultation" where Lord Robens argues a very strong case for consulting and discussing with the workers about pretty well anything and everything, including the balance sheet and what should be done with the company profits. To those of us already committed to far greater industrial democracy and worker participation this is not revolutionary stuff, but in most British boardrooms it probably reads like the "Thoughts of Chairman Alf".

As a handbook for all managers in industry, with its chapters on work, the personnel manager, the nature of trade unionism, consultation, safety, delegation, education of management and career planning, Lord Robens's book is essential and enlightened reading. It is also an interesting insight into the man, his background, achievements and philosophy.

I. KUCZYNSKI

\section{POWER STRUGGLES IN GERMANY}

\section{Das Gesellschaftsbild des Ingenieurs}

Zum Politischen Verhalten der Technischen Intolligenz in Doutschland. By Gerd Hortleder. Pp. 226. (Suhrkamp Verlag: Frankfurt, 1970.) n.p.

THe title of this paperback disguises the fact that it is primarily an analysis of the history of the Verein Deutscher Ingenieure-the Association of German Engineers. On this peg $\mathrm{Dr}$ Hortleder, a sociologist, hangs an interesting disquisition on the German engineor's view of society and the political attitudes of the German "technical intelligentsia". As the use of this odious term suggests, the style is an unfortunate mélange of sociological abstractions and occasional syntactical convolutions: George Steiner would find support here for his melancholy conviction that the year's of the Nazi régime brought about an irreversible deterioration in the German language.

The book should, however, be of distinct interest to the historian of scientific and engineering institutions. The authors writes of German engineers only, and makes few comparisons with other lands. The principal thesis, which he illustrates by extracts from the writings of early ongineers, from sociological statistics and from the power struggles within tho VDI and related bodies, is that German engineers have too commonly regarded themselves as technical experts first and last and have abdicated their 